\title{
DETERMINAN INISIASI MENYUSU DINI (IMD) WANITA USIA 15-49 TAHUN DI INDONESIA (ANALISIS DATA SDKI 2012)
}

\author{
Nur Aini ${ }^{1}$ and Budyanra ${ }^{2}$ \\ 1Badan Pusat Statistik Kabupaten Gorontalo Utara, Indonesia, nur.aini@bps.go.id \\ 2Politeknik Statistika STIS, Indonesia, budy@stis.ac.id \\ Indonesian Journal of Statistics and Its Applications (eISSN:2599-0802) \\ Vol 3 No 1 (2019), 33 - 48 \\ Copyright ( 2019 Nur Aini and Budyanra. This is an open-access article distributed under the Creative \\ Commons Attribution License, which permits unrestricted use, distribution, and reproduction in any
} medium, provided the original work is properly cited.

\begin{abstract}
Early Breastfeeding Initiation (EBI) is one of the most effective ways to reduce neonatal mortality in Indonesia. Implementation of EBI in Indonesia in 2012 is still in the "adequate" category according to World Health Organization (WHO) and is in "less" category according to International Baby Food Action Network (IBFAN). Implementation of EBI in Indonesia is still under other ASEAN Association countries such as Philippines, Cambodia and Myanmar. The low application of the EBI is thought to be influenced by maternal factors as well as environmental factors. This study aims to determine the factors that affect the status of $\mathrm{EBI}$ in Indonesia and see a general description of the status of EBI based on its characteristics. The data used are raw data of IDHS 2012 and analyzed using logistic regression model of proportional partial ordinal odds. The results obtained are the variables of antenatal care visit, maternal working status, place of residence, place of delivery, method of delivery, and parity are determinant of EBI status in Indonesia.
\end{abstract}

Keywords: early breastfeeding initiation, Indonesia Demographic and Health Surveys 2012, neonatal mortality rate, ordinal logistic regression, partial proportional odds.

\section{Pendahuluan}

Angka Kematian Bayi (AKB) Indonesia pada tahun 2012 adalah sebesar 32 kematian per 1000 kelahiran hidup, dimana enam puluh persen kematian bayi tersebut terjadi pada umur kurang dari satu bulan (KEMENKES RI, 2013). Kematian bayi yang terjadi pada umur kurang dari satu bulan disebut kematian neonatal. Angka Kematian Neonatal (AKN) Indonesia pada tahun 2012 adalah sebesar 19 kematian per 10000

\footnotetext{
“Received Oct 2018; Accepted Des 2018; Published online on Feb 2019
} 
kelahiran hidup. Angka tersebut masih jauh dari target AKN dalam Sustainable Development Goals (SDGs), yaitu sebesar 12 kematian per 1000 kelahiran hidup.

Salah satu cara yang paling efektif untuk mengurangi kematian neonatal adalah dengan memberikan ASI sesegera mungkin setelah kelahiran atau yang sering disebut dengan istilah Inisiasi Menyusu Dini (IMD) (Roesli, 2008). IMD adalah pemberian ASI segera setelah bayi dilahirkan, biasanya dalam waktu 30 menit hingga satu jam pasca bayi dilahirkan (KEMENKES RI, 2014). Menurut Roesli (2008), IMD memberikan manfaat yang tidak hanya baik bagi bayi namun juga bagi ibu, dimana dengan melakukan IMD risiko perdarahan postpartum pada ibu dapat diturunkan. Menurut penelitian yang dilakukan oleh Edmond et al. (2006) dengan melakukan IMD dapat mengurangi kematian bayi sebesar $22 \%$. Mullany et al. (2008) juga menyatakan bahwa ibu yang tidak melakukan IMD anaknya memiliki kecenderungan yang lebih tinggi untuk mengalami kematian, yaitu sebesar 2,80.

Di Indonesia, persentase IMD pada tahun 2012 mencapai 49,3 persen (KEMENKES RI, 2013). Dari angka tersebut, Indonesia berada di posisi ke-72 dari 130 negara berdasarkan hasil pengumpulan data yang dilakukan oleh UNICEF pada periode tahun 2010-2015, lebih rendah bila dibanding beberapa negara ASEAN lainnya yaitu Filipina (49,7 persen\%), Kamboja (62,6\%), dan Myanmar (75,8\%). World Health Organization (WHO) pada tahun 2003 mengklasifikasikan implementasi IMD menjadi empat kategori, yaitu poor (0-29,9\%), fair (30-49,9\%), good (50-89,9\%), dan very good (90-100\%). Berdasarkan kategori tersebut, dapat diketahui bahwa Indonesia masih berada pada kategori fair atau cukup dan menunjukkan bahwa Indonesia masih harus meningkatkan kembali pelaksanaan IMD. International Baby Food Action (IBFAN) Asia dan Breastfeeding Promotion Network of India (BPNI) juga melakukan sebuah studi untuk mengetahui status menyusui di 33 negara yang dilihat dari skor WBTi (World Breastfeeding Trend Initiative). Salah satu indikator yang digunakan adalah pemberian ASI dini atau IMD. Dari hasil penelitian tersebut, Indonesia berada di posisi ke-4 terbawah dan berada pada level insufficient atau kurang. Hal ini sangatlah mengkhawatirkan, terlebih setelah diketahui bahwa IMD sangatlah penting untuk mengurangi kematian neonatal.

Rendahnya persentase status IMD tersebut telah menjadi sorotan pemerintah Indonesia. Pemerintah telah melakukan berbagai upaya untuk meningkatkan persentase status IMD tersebut dengan melakukan berbagai program. Beberapa program pemerintah antara lain adanya Keputusan Menteri Kesehatan RI No. 540/Menkes/SK/IV/2004 tentang Pemberian ASI secara Eksklusif pada Bayi dan diterbitkannya Buku Asuhan Persalinan Normal (APN) oleh Departemen Kesehatan Republik Indonesia. Selain itu, pemerintah juga bekerja sama dengan USAID (United States Agency International Development) dalam suatu program yang disebut USAIDKINERJA. Program ini dibuat dalam rangka meningkatkan tata kelola penyediaan layanan publik. Salah satu tujuan yang ingin dicapai adalah untuk meningkatkan pemberian IMD dan ASI Eksklusif di 5 provinsi di Indonesia. Dengan adanya programprogram tersebut, maka sudah seharusnya terjadi peningkatan terkait partisipasi IMD, namun pada faktanya kondisi IMD di Indonesia masih rendah.

Berdasarkan latar belakang tersebut, penelitian ini bertujuan untuk melihat gambaran umum berdasarkan karakteristik wanita usia 15-49 tahun yang pernah melahirkan di tahun 2007-2011 berdasarkan status IMD serta mengetahui variabel- 
variabel yang memengaruhi status IMD di Indonesia tahun 2012. Untuk menjawab tujuan, digunakan analisis deskriptif dan analisis inferensia regresi logistik ordinal serta teori perilaku kesehatan Green sebagai dasar kerangka pikir penelitian berikut (Gambar 1).

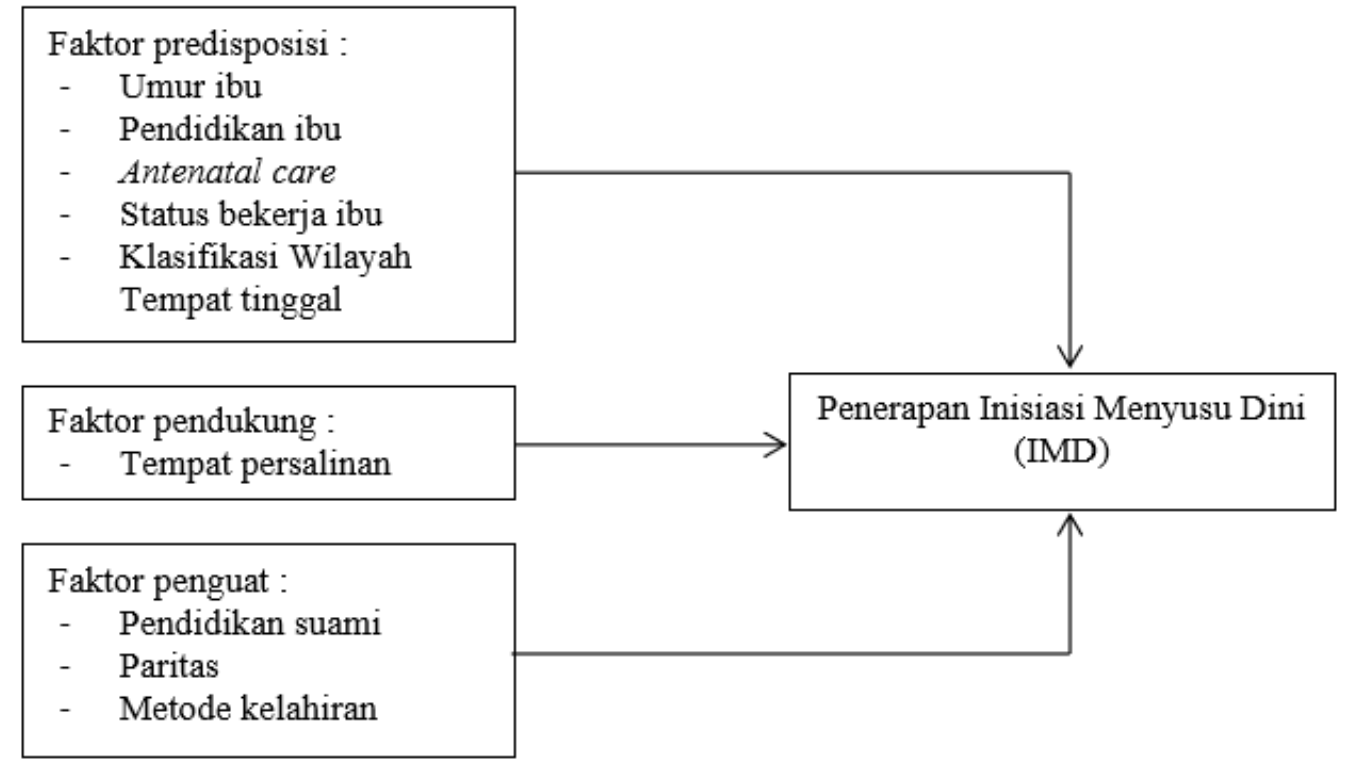

\section{Gambar 1: Kerangka Pikir Penelitian}

Teori tersebut menyatakan bahwa perilaku manusia dipengaruhi oleh dua faktor pokok, yaitu perilaku dan diluar perilaku. Faktor perilaku sendiri ditentukan oleh tiga faktor, yaitu : faktor predisposisi (predisposing factor), faktor pendorong (enabling factor), dan faktor penguat (reinforcement factor). Berdasarkan teori ini, maka status IMD digunakan sebagai variabel respons, sedangkan variabel umur ibu, tingkat pendidikan ibu, kunjungan antenatal care, tempat tinggal, tempat persalinan, tingkat pendidikan suami, paritas, dan metode persalinan sebagai variabel penjelas.

Banyak penelitian yang telah dilakukan terkait IMD dan faktor-faktor yang memengaruhinya, baik di dalam negeri maupun luar negeri. Salah satu penelitian di luar negeri dilakukan oleh Acharya dan Khanal (2015) di Nepal. Tujuan penelitian tersebut adalah mengetahui hubungan antara pendidikan ibu dan variabel-variabel lain dengan implementasi IMD. Hasil yang diperoleh menunjukkan bahwa terdapat hubungan antara pendidikan ibu, tempat tinggal, kunjungan antenatal care, tempat melahirkan, dan metode persalinan terhadap pemberian IMD.

Nelvi (2004) juga melakukan penelitian di Indonesia untuk mengetahui variabel sosial-demografi yang memengaruhi IMD dan memperoleh hasil yang menyatakan bahwa pendidikan ibu dan status bekerja ibu merupakan faktor yang memengaruhi ibu dalam memberikan IMD. Penelitian lain di Indonesia dilakukan oleh Suryani dan Mularsih (2011). Hasil penelitian menunjukkan adanya hubungan antara dukungan suami, yang dilihat melalui tingkat pendidikan suami dengan keputusan ibu untuk melakukan IMD. 


\section{Metodologi}

\subsection{Bahan dan Data}

Data yang digunakan adalah raw data yang diperoleh dari Survei Demografi dan Kesehatan Indonesia (SDKI) tahun 2012. Dalam SDKI 2012, terdapat empat macam kuesioner yang digunakan, yaitu untuk rumah tangga (SDKI12-RT), wanita usia subur (SDKI12-WUS), pria kawin (SDKI12-PK), dan remaja pria (SDKI12-RP). Kuesioner yang digunakan dalam penelitian ini adalah kuesioner yang terkait dengan wanita usia subur, yaitu SDKI12-WUS.

Dalam pelaksanaannya, metode pemilihan sampel yang digunakan adalah Three Stage Sampling. Tahap pertama untuk memilih Primary Sampling Unit (PSU), yaitu kelompok Blok Sensus (BS) yang berdekatan dengan menggunakan Probability Proportional to Size (PPS) dengan size jumlah rumah tangga. Tahap kedua juga dilakukan secara PPS yaitu untuk memilih satu BS dari setiap PSU dengan size jumlah rumah tangga. Tahap ketiga yaitu memilih 25 rumah tangga biasa di setiap BS terpilih secara sistematik. Pengumpulan data dilakukan pada bulan Mei hingga Agustus 2012 di 33 Provinsi di Indonesia oleh Badan Pusat Statistik yang bekerja sama dengan Badan Kependudukan dan Keluarga Berencana Nasional.

Jumlah BS yang terpilih dalam SDKI 2012 adalah sebanyak 1840 BS. Dari BS tersebut, diperoleh sebanyak 45.607 wanita usia 15-49 tahun yang selesai diwawancarai. Dalam penelitian ini, dipilih wanita yang pernah melahirkan di tahun 2007-2011, dengan jumlah sebanyak 14.366 wanita usia 15-49 tahun. Setelah responden yang tidak memenuhi syarat dikeluarkan dari penelitian, jumlah amatan akhir adalah sebanyak 14.097 wanita usia 15-49 tahun yang pernah melahirkan di tahun 2007-2011.

\subsection{Metode Analisis}

Dalam melakukan analisis data, penelitian ini menggunakan analisis deskriptif dan analisis inferensia. Untuk analisis deskriptif, penelitian ini menggunakan tabel dan grafik dengan tujuan melihat gambaran umum status IMD berdasarkan karakteristik wanita usia 15-49 tahun, sedangkan analisis inferensia menggunakan regresi logistik ordinal untuk mengetahui variabel-variabel yang memengaruhi status IMD. Variabel respons yang digunakan merupakan variabel dengan tiga kategori berdasarkan waktu pemberian ASI pertama setelah kelahiran, yaitu kurang dari satu jam, 1-24 jam, dan lebih dari $24 \mathrm{jam}$. Sedangkan variabel penjelas yang digunakan adalah umur ibu, tingkat pendidikan ibu, jumlah kunjungan antenatal care, status bekerja ibu, klasifikasi wilayah tempat tinggal, tempat bersalin, tingkat pendidikan suami, paritas, dan metode persalinan.

Di dalam regresi logistik ordinal, terdapat tiga model yang sering digunakan, yaitu model adjacent-category, continuation ratio, dan cumulative logit. Penelitian ini menggunakan model cummulative logit. Dalam model cumulative logit terdapat $\mathrm{J}-1$ cara yang dapat digunakan untuk membandingkan kategori pada variabel respons, cummulative logits, yaitu proportional odds, non-proportional odds, dan partial proportional odds. Perbedaan ketiga moel tersebut terletak pada penerapan asumsi parallel lines. 
Dalam regresi logistik ordinal terdapat asumsi yang harus dipenuhi, yaitu asumsi parallel lines. Asumsi parallel lines adalah asumsi yang menyatakan bahwa dalam model regresi logistik ordinal, parameter-parameter (slope) dari model tidak berubah untuk kategori variabel respons yang berbeda. Dengan kata lain, korelasi antara variabel penjelas dengan variabel respons tidak berubah untuk setiap kategori variabel respons dan estimasi parameter (slope) tidak berubah untuk cut-off point yang berbeda (Ari dan Yildiz, 2014). Saat asumsi parallel lines terpenuhi, maka regresi logistik ordinal model proportional odds dapat digunakan. Namun saat asumsi tersebut tidak terpenuhi, maka dapat menggunakan metode analisis lain, yaitu regresi logistik multinomial. Namun dengan menggunakan regresi logistik multinomial akan menghilangkan adanya urutan yang terdapat pada variabel respons. Oleh karena itu, alternatif lain yang dapat digunakan adalah tetap menggunakan regresi logistik ordinal namun dengan model yang berbeda, yaitu model partial proportional odds atau model non-proportional odds.

Langkah pertama yang dilakukan dalam analisis regresi logistik ordinal dalam penelitian ini adalah melakukan estimasi parameter untuk memperoleh nilai estimasi parameter $\alpha$ (intercept) dan $\beta$ (slope). Metode estimasi yang digunakan adalah metode Maximum Likelihood Estimation (MLE) (Williams, 2006; Agresti, 2010; Hosmer et al., 2013) dengan proses iterasi Fisher Scoring.

$$
\begin{aligned}
L(\beta) & =\prod_{i=1}^{n} \prod_{j=1}^{J} \pi_{j}\left(x_{i}\right)^{y_{j i}} \\
& =\prod_{i=1}^{n}\left\{\left[\pi_{1}\left(x_{i}\right)^{y_{1 i}}\right]\left[\pi_{2}\left(x_{i}\right)^{y_{2 i}}\right] \ldots\left[\pi_{J}\left(x_{i}\right)^{y_{j i}}\right]\right\}
\end{aligned}
$$

Setelah hasil estimasi parameter diperoleh, selanjutnya dilakukan pengujian asumsi parallel lines dengan statistik uji PL yang mengikuti distribusi $X^{2}$ dengan derajat bebas $p(j-2)$, dimana $p$ adalah jumlah parameter $\beta$ dan $j$ adalah jumlah kategori variabel respons.

$$
P L=-2 \ln \left[\frac{L o}{L_{1}}\right] \sim \chi_{\alpha, p(J-2)}^{2}
$$

Pengujian ini bertujuan untuk mengetahui apakah regresi logistik odinal model proportional odds sesuai dengan data. Saat nilai $\mathrm{PL}>\mathrm{X}^{2} 0,05 ;(\mathrm{J}-2)$ atau nilai $p$-value $<$ 0,05 maka dapat disimpulkan bahwa dengan tingkat kepercayaan 95 persen asumsi parallel llines tidak terpenuhi sehingga model proportional odds tidak sesuai dengan data dan selanjutnya dilakukan uji Brant untuk mengetahui model manakah yang lebih tepat untuk digunakan antara model non-proportional odds atau partial proportional odds. 


$$
\text { Brant }=-2 \ln \left[\frac{L o}{L_{1}}\right] \sim \chi_{\alpha,\left(p_{1}-p_{0}\right)}^{2}
$$

Statistik uji yang digunakan adalah statistik uji Brant yang mengikuti distribusi $\mathrm{X}^{2}$ dengan derajat bebas (j-2), dimana j adalah jumlah kategori variabel respons. Saat hasil pengujian Brant menunjukkan nilai statistik uji Brant $>X^{2}{ }_{0,05 ; 1}$ maka dengan tingkat kepercayaan 95 persen dapat dikatakan bahwa parameter $\beta$ ke-k tidak memenuhi asumsi parallel lines. Saat hanya sebagian parameter $\beta$ tidak memenuhi, maka model yang digunakan adalah model partial proportional odds, sedangkan saat seluruh parameter $\beta$ tidak memenuhi asumsi, maka model yang digunakan adalah model nonproportional odds. Setelah ditentukan model mana yang akan digunakan, dilakukan estimasi parameter lagi dengan menerapkan model baru yang sesuai dengan data.

Selanjutnya, dilakukan pengujian kesesuaian model. Uji yang digunakan adalah LR Chi-square dengan menggunakan statistik uji $\mathrm{G}$ yang berdistribusi $\mathrm{X}^{2}$ dengan derajat bebas $\left(p_{1}-p_{0}\right)$, dimana $p_{1}$ adalah jumlah parameter $\beta$ dari model yang lebih kompleks dan $p_{0}$ adalah jumlah parameter $\beta$ dari model yang lebih sederhana.

$$
G=-2 \ln \left[\frac{L o}{L_{1}}\right] \sim \chi_{\alpha,\left(p_{1}-p_{0}\right)}^{2}
$$

Langkah berikutnya adalah pengujian signifikansi penduga parameter baik secara simultan maupun secara parsial. Pengujian signifikansi penduga parameter secara simultan menggunakan statistik uji $\mathrm{G}$ yang mengikuti distribusi $\mathrm{X}^{2}$ dengan derajat bebas $p$, dimana $p$ adalah jumlah parameter $\beta$.

$$
G=-2 \ln \left[\frac{L o}{L_{1}}\right] \sim \chi_{\alpha, p}^{2}
$$

Pengujian signifikansi penduga parameter secara parsial dilakukan dengan menggunakan statistik uji Wald yang mengikuti distribusi $X^{2}$ dengan derajat bebas 1 . Saat nilai statistik uji $\mathrm{W}>\mathrm{X}^{2} 0,05 ; 1$ atau $p$-value $<0,05$ artinya dengan tingkat kepercayaan 95 persen dapat dikatakan bahwa variabel penjelas ke-k berpengaruh terhadap status IMD.

$$
|W|=\frac{\widehat{\beta_{k}}}{\operatorname{se}\left(\widehat{\beta_{k}}\right)} \sim Z \alpha / 2
$$

Berdasarkan seluruh langkah pengujian di atas, maka diperoleh model regresi logistik ordinal sebagai berikut:

$$
\begin{aligned}
\operatorname{Logit}[P(Y>0 \mid x)]= & \alpha+\beta_{11} \text { umur }+\beta_{21} \text { pendidikan_ibu }+\beta_{31} \text { anc }+\beta_{41} \text { status_kerja }+ \\
& \beta_{51 \text { tempat_tinggal }+}+\beta_{61} \text { tempat_persalinan }+\beta_{71} \text { pendidikan_suami }+ \\
& \beta_{81} \text { paritas }+\beta_{91} \text { metode_persalinan }
\end{aligned}
$$




$$
\begin{aligned}
\operatorname{Logit}[P(Y>1 \mid x)]= & \alpha+\beta_{12 \text { umur }}+\beta_{22} \text { pendidikan_ibu }+\beta_{32} \text { anc }+\beta_{42} \text { status_kerja }+ \\
& \beta_{52 \text { tempat_tinggal }+\beta_{62} \text { tempat_persalinan }+\beta_{72} \text { pendidikan_suami }+}+ \\
& \beta_{82} \text { paritas }+\beta_{92} \text { metode_persalinan }
\end{aligned}
$$

\section{Hasil dan Pembahasan}

\section{Analisis Deskriptif}

Berdasarkan Gambar 2, sebanyak 58,9 persen wanita usia 15-49 tahun di Indonesia telah melakukan IMD satu jam setelah kelahiran yang menunjukkan bahwa Indonesia telah tergolong "baik" dalam pemberian IMD. Selanjutnya, pemberian ASI pertama antara 1-24 jam setelah kelahiran ada sebanyak 21,2 persen dan pemberian ASI pertama setelah 24 jam sebanyak 19,9 persen.

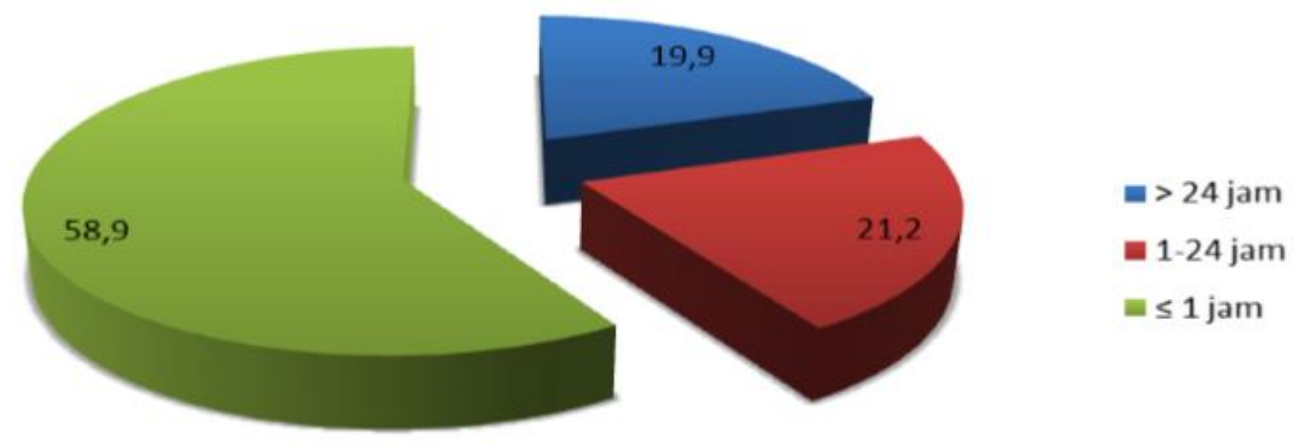

Sumber : SDKI 2012, diolah

Gambar 2: Persentase status IMD wanita usia 15-49 tahun di Indonesia tahun 2012.

Selain melihat gambaran umum wanita usia 15-49 tahun yang pernah melahirkan di tahun 2007-2011 yang melakukan IMD, perlu diketahui pula gambaran wanita usia 15-49 tahun yang pernah melahirkan di tahun 2007-2011 (selanjutnya disebut ibu) yang melakukan IMD berdasarkan faktor-faktor yang memengaruhinya, seperti faktor predisposisi (umur ibu, tingkat pendidikan ibu, kunjungan antenatal care, status bekerja ibu, dan tempat tinggal), faktor pendukung (tempat persalinan), dan faktor penguat (tingkat pendidikan suami, paritas, dan metode persalinan).

Dilihat dari umur ibu, persentase ibu yang melakukan IMD satu jam setelah kelahiran baik ibu berusia 20-35 tahun maupun kurang dari 20 dan lebih dari 35 adalah $58,9 \%$. Persentase yang sama juga ditunjukkan untuk kategori status IMD 1-24 jam $(21,2 \%)$ dan lebih dari 24 jam (19,9\%). Hal ini menunjukkan tidak adanya perbedaan yang signifikan antara status IMD dengan umur ibu. Kemudian dilihat dari tingkat pendidikan ibu, sebanyak $60,2 \%$ ibu yang berpendidikan SMP ke bawah melakukan IMD satu jam, 19,28\% melakukan IMD dalam 1-24 jam, dan 20\% melakukan IMD lebih 
dari 24 jam setelah kelahiran. Sedangkan ibu yang berpendidikan SMA ke atas, sebanyak 56,9\% nya melakukan IMD satu jam setelah kelahiran. Hal ini menunjukkan bahwa ibu yang berpendidikan SMP ke bawah memiliki persentase yang lebih besar dibanding ibu yang berpendidikan SMA ke atas dalam pelaksanaan IMD satu jam setelah kelahiran.

Berdasarkan banyaknya kunjungan antenatal care, ibu yang melakukan kunjungan minimal empat kali lebih banyak yang melakukan IMD satu jam $(59,3 \%)$ dibandingkan yang melakukan IMD 1-24 jam (21,2\%) dan lebih dari 24 jam (19,5\%). Sedangkan pada ibu yang melakukan kunjungan kurang dari empat kali memiliki persentase yang lebih kecil $(55,1 \%)$ dibandingkan ibu yang melakukan kunjungan minimal empat kali dalam hal melakukan IMD satu jam setelah kelahiran. Kemudian ibu yang bekerja memiliki persentase yang lebih besar dalam melakukan IMD satu jam $(60,6 \%)$ dibandingkan kategori status IMD lainnya. Angka tersebut lebih besar pula dibandingkan ibu yang tidak bekerja dan melakukan IMD satu jam setelah kelahiran $(57,3 \%)$ yang artinya ibu yang bekerja lebih cenderung untuk melakukan IMD satu jam setelah kelahiran dibandingkan ibu yang tidak bekerja.

Tabel 1: Persentase karakteristik wanita usia 15-49 tahun berdasarkan status IMD

\begin{tabular}{|c|c|c|c|c|c|}
\hline \multirow[t]{2}{*}{ No. } & \multirow[t]{2}{*}{ Variabel Penjelas } & \multirow{2}{*}{$\begin{array}{c}\text { Kategori Variabel } \\
\text { Penjelas }\end{array}$} & \multicolumn{3}{|c|}{ Status IMD (\%) } \\
\hline & & & $>24$ jam & 1-24 jam & $\leq 1 \mathrm{jam}$ \\
\hline \multirow[t]{2}{*}{1.} & \multirow[t]{2}{*}{ Umur ibu } & $<20$ dan $>35$ tahun & 19,9 & 21,2 & 58,9 \\
\hline & & $20-35$ tahun & 19,9 & 21,2 & 58,9 \\
\hline \multirow[t]{2}{*}{2.} & \multirow{2}{*}{$\begin{array}{l}\text { Tingkat pendidikan } \\
\text { ibu }\end{array}$} & SMP ke bawah & 20,0 & 19,8 & 60,2 \\
\hline & & SMA ke atas & 19,8 & 23,3 & 56,9 \\
\hline \multirow[t]{2}{*}{3.} & \multirow[t]{2}{*}{ Antenatal care } & $<4$ kali & 23,8 & 21,1 & 55,1 \\
\hline & & $\geq 4$ kali & 19,5 & 21,2 & 59,3 \\
\hline \multirow[t]{2}{*}{4.} & \multirow[t]{2}{*}{ Status bekerja ibu } & Tidak bekerja & 21,1 & 21,6 & 57,3 \\
\hline & & Bekerja & 18,6 & 20,8 & 60,6 \\
\hline \multirow[t]{2}{*}{5.} & \multirow[t]{2}{*}{ Tempat tinggal } & Perdesaan & 21,8 & 19,6 & 58,6 \\
\hline & & Perkotaan & 18,0 & 22,8 & 59,2 \\
\hline \multirow[t]{2}{*}{6.} & \multirow[t]{2}{*}{ Tempat persalinan } & Non-fasilitas kesehatan & 22,4 & 19,1 & 58,6 \\
\hline & & Fasilitas kesehatan & 18,6 & 22,4 & 59,1 \\
\hline \multirow[t]{2}{*}{7.} & \multirow{2}{*}{$\begin{array}{l}\text { Tingkat pendidikan } \\
\text { suami }\end{array}$} & SMP ke bawah & 20,1 & 19,8 & 60,1 \\
\hline & & SMA ke atas & 19,7 & 23,0 & 57,3 \\
\hline \multirow[t]{2}{*}{8.} & \multirow[t]{2}{*}{ Paritas } & Primipara & 23,4 & 22,4 & 54,2 \\
\hline & & Multipara & 17,9 & 20,5 & 61,7 \\
\hline \multirow[t]{2}{*}{9.} & \multirow[t]{2}{*}{ Metode persalinan } & Caesar & 30,0 & 28,0 & 42,0 \\
\hline & & Normal & 18,5 & 20,3 & 61,2 \\
\hline
\end{tabular}

Lebih dari setengah ibu yang tinggal di wilayah perkotaan telah melakukan IMD satu jam setelah kelahiran yaitu sebesar 59,2 dan merupakan yang tertinggi dibandingkan status IMD 1-24 jam (22,8\%) dan lebih dari 24 jam (18\%). Sedangkan persentase ibu yang tinggal di perdesaan dan melakukan IMD satu jam adalah sebesar $58,6 \%$, angka ini lebih rendah dibandingkan ibu yang tinggal di perkotaan dan melakukan IMD satu jam, artinya ibu yang tinggal di perkotaan memiliki 
kecenderungan yang lebih tinggi untuk melakukan IMD satu jam setelah kelahiran. Jika dilihat dari ibu yang bersalin di tempat fasilitas kesehatan, sebanyak $59,1 \%$ ibu melakukan IMD satu jam, 22,4\% melakukan IMD 1-24 jam, dan 18,6\% melakukan IMD lebih dari 24 jam setelah kelahiran. Terdapat 58,6\% ibu yang melakukan IMD satu jam dan bersalin di tempat non-fasilitas kesehatan. Angka ini lebih rendah dibandingkan ibu yang melahirkan di fasilitas kesehatan dan melakukan IMD satu hari setelah kelahiran, artinya ibu yang melahirkan di fasilitas kesehatan lebih cenderung untuk melakukan IMD satu jam setelah kelahiran.

Ibu yang memiliki suami berpendidikan SMP ke bawah lebih banyak yang melakukan IMD satu jam dibandingkan IMD 1-24 jam dan lebih dari 24 jam, sedangkan pada ibu yang memiliki suami berpendidikan SMA ke atas, sebagian besar melakukan IMD satu jam setelah kelahiran. Kemudian dilihat dari status IMD satu jam dan paritas, ibu multipara memiliki persentase sebesar $61,7 \%$ dan persentase tersebut lebih besar dibandingkan ibu primipara yaitu 54,2\%. Hal ini menunjukkan bahwa ibu multipara lebih cenderung untuk melakukan IMD satu jam setelah kelahiran. Selanjutnya, ibu yang besalin secara normal lebih banyak yang melakukan IMD satu jam yaitu sebesar $61,2 \%$ dibandingkan dengan IMD 1-24 jam yaitu 20,3\% dan IMD lebih dari 24 jam yaitu $18,5 \%$. Besarnya persentase ibu yang melakukan IMD satu jam dan melahirkan secara normal dengan yang melahirkan secara caesar mengindikasikan bahwa ibu yang melahirkan secara normal memiliki partisipasi yang lebih besar untuk melakukan IMD satu jam dibandingkan ibu yang melahirkan secara caesar.

\section{Analisis Inferensia}

Pengujian pertama adalah pengujian estimasi parameter dan menghasilkan model proportional odds. Selanjutnya, dilakukan pengujian asumsi parallel lines, dengan hasil disajikan pada Tabel 2 sebagai berikut.

Tabel 2: Hasil penghitungan nilai statistik uji asumsi parallel lines

\begin{tabular}{cccc}
\hline $\boldsymbol{P L}$ & $\mathbf{d f}$ & $\chi_{\mathbf{0}, 05 ; 9}^{2}$ & $\boldsymbol{p}$-value \\
\hline 80,61 & 9 & 16,919 & 0,000 \\
\hline
\end{tabular}

Tabel 2 menunjukkan bahwa nilai statistik uji PL yaitu sebesar 83,27 jauh lebih besar dibandingkan nilai $X^{2} 0,05 ; 9$ yaitu sebesar 16,919 sehingga dapat disimpulkan bahwa dengan tingkat kepercayaan 95 persen dapat dikatakan asumsi parallel lines tidak terpenuhi dan model proportional odds tidak sesuai dengan data. Selanjutnya, untuk mengetahui model apa yang sesuai dengan data maka dilakukan uji brant.

Berdasarkan Tabel 3, dapat diketahui bahwa hanya sebagian variabel penjelas yang tidak memenuhi asumsi parallel lines, yaitu variabel penjelas yang memiliki nilai $p$-value $<0,05$ sehingga model yang sesuai dengan data adalah model partial proportional odds. Setelah diperoleh model yang sesuai dengan data, selanjutnya dilakukan pengujian kesesuaian model. Pengujian pertama adalah membandingkan antara model partial proportional odds dengan non proportional odds. 
Tabel 3: Hasil pengujian Brant secara parsial

\begin{tabular}{lccc}
\hline Variabel Penjelas & Brant & df & p-value \\
\hline Umur & 0,40 & 1 & 0,528 \\
Pendidikan ibu & 4,36 & 1 & $0,037^{*}$ \\
Antenatal care & 0,23 & 1 & 0,635 \\
Status bekerja ibu & 0,85 & 1 & 0,358 \\
Tempat tinggal & 5,76 & 1 & $0,016^{*}$ \\
Tempat persalinan & 13,05 & 1 & $0,000^{*}$ \\
Pendidikan suami & 3,89 & 1 & $0,048^{*}$ \\
Paritas & 5,47 & 1 & $0,019^{*}$ \\
Metode persalinan & 0,22 & 1 & 0,639 \\
\hline
\end{tabular}

Hasil yang diperoleh menunjukkan bahwa nilai statistik uji $\mathrm{G}$ yaitu sebesar 81,66 jauh lebih besar dibanding nilai $X^{2} 0,05 ; 5$ yaitu sebesar 11,070 yang berarti dengan tingkat kepercayaan 95 persen dapat dikatakan bahwa model partial proportional odds merupakan model yang sesuai dengan data. Pengujian kedua (Tabel 4) adalah membandingkan antara model partial proportional odds dengan non-proportional odds dengan hasil nilai statistik uji $\mathrm{G}$ yaitu sebesar 1,61 yang lebih kecil dibandingkan nilai $\mathrm{X}^{2} 0,05 ; 4$ yaitu sebesar 9,488 . Hasil tersebut menunjukkan bahwa dengan tingkat kepercayaan 95 persen bahwa model yang sesuai dengan data adalah partial proportional odds.

Tabel 4: Hasil pengujian kesesuaian model dengan LR Chi-Square

\begin{tabular}{cccc}
\hline $\boldsymbol{G}$ & $\mathbf{d f}$ & $\chi_{0,05 ; 4}^{2}$ & $\boldsymbol{p}$-value \\
\hline 1,61 & 4 & 9,488 & 0,8075 \\
\hline
\end{tabular}

Berikutnya adalah pengujian signifikansi penduga parameter secara simultan dan parsial disajikan pada Tabel 5. Secara simultan, hasil pengolahan yang diperoleh menunjukkan bahwa nilai statistik uji $G$ yaitu sebesar 528,99 jauh lebih besar dibanding nilai $X^{2} 0,05 ; 14$ yaitu 23,685 sehingga kesimpulan yang diambil adalah dengan tingkat kepercayaan 95 persen dapat dikatakan bahwa terdapat minimal satu variabel penjelas yang berpengaruh secara signifikan terhadap variabel status IMD.

Tabel 5: Hasil pengujian penduga parameter secara simultan

\begin{tabular}{cccc}
\hline $\boldsymbol{G}$ & $\mathbf{d f}$ & $\boldsymbol{x}_{0,05 ; 9}^{2}$ & $\boldsymbol{p}$-value \\
\hline 528,99 & 14 & 23,685 & 0,000 \\
\hline
\end{tabular}

Pada model partial proportional odds, diperoleh dua model yang digunakan dalam penelitian ini dimana model pertama merupakan model yang menunjukkan status IMD dalam waktu satu hari setelah kelahiran sedangkan model kedua menunjukkan status IMD dalam waktu satu jam setelah kelahiran. Dari Tabel 6, diperoleh hasil yang menunjukkan bahwa pada model pertama memiliki enam variabel penjelas yang 
signifikan memengaruhi variabel status IMD. Variabel penjelas tersebut antara lain kunjungan antenatal care, status bekerja ibu, tempat tinggal, paritas, dan metode persalinan. Berikut adalah persamaan yang diperoleh untuk model 1.

$\begin{aligned} \operatorname{Logit}[\mathrm{P}(\mathrm{Y}>0 \mid \mathrm{x})]= & -0,2756-0,0572 \mathrm{umur}+0,0556 \text { pendidikan_ibu }+0,1802 \mathrm{anc}^{*}+ \\ & 0,0896 \text { status_kerja* }^{*}+0,1119 \text { tempat_tinggal } \\ & \text { 0,4753tempat_persalinan }{ }^{*}+0,0239 \text { pendidikan_suami } \\ & \text { 0,3646paritas }{ }^{*}+0,9617 \text { metode_persalinan }^{*}\end{aligned}$

Keterangan $\quad:$ *) Signifikan pada $\alpha=0,05$

Tabel 6: Hasil pengujian penduga parameter secara parsial

\begin{tabular}{|c|c|c|c|c|c|}
\hline Model & Variabel & Koefisien & SE & Wald & $p$-value \\
\hline \multirow[t]{10}{*}{1} & Konstanta & $-0,2756$ & 0,0842 & 10,6929 & $0,001^{*}$ \\
\hline & Umur & $-0,0572$ & 0,0399 & 2,0449 & 0,152 \\
\hline & Pendidikan ibu & 0,0556 & 0,0519 & 1,1449 & 0,285 \\
\hline & Antenatal care & 0,1802 & 0,0481 & 14,0625 & $0,000^{*}$ \\
\hline & Status bekerja ibu & 0,0896 & 0,0331 & 7,3441 & $0,007^{*}$ \\
\hline & Tempat tinggal & 0,1119 & 0,0469 & 5,6644 & $0,017^{*}$ \\
\hline & $\begin{array}{l}\text { Tempat } \\
\text { persalinan }\end{array}$ & 0,4753 & 0,0490 & 93,8961 & $0,000^{*}$ \\
\hline & Pendidikan suami & 0,0239 & 0,0502 & 0,2304 & 0,634 \\
\hline & Paritas & 0,3646 & 0,0429 & 7,0801 & $0,000^{*}$ \\
\hline & $\begin{array}{l}\text { Metode } \\
\text { persalinan }\end{array}$ & 0,9617 & 0,0525 & 335,6224 & $0,000^{*}$ \\
\hline \multirow[t]{10}{*}{2} & Konstanta & $-1,0714$ & 0,0812 & 173,9761 & $0,000^{*}$ \\
\hline & Umur & $-0,0572$ & 0,0399 & 2,0449 & 0,152 \\
\hline & Pendidikan ibu & $-0,0422$ & 0,0433 & 0,9409 & 0,330 \\
\hline & Antenatal care & 0,1802 & 0,0481 & 14,0625 & 0,000 * \\
\hline & $\begin{array}{l}\text { Status bekerja } \\
\text { ibu }\end{array}$ & 0,0896 & 0,0331 & 7,3441 & $0,007^{*}$ \\
\hline & Tempat tinggal & 0,0188 & 0,0389 & 0,2304 & 0,630 \\
\hline & $\begin{array}{l}\text { Tempat } \\
\text { persalinan }\end{array}$ & 0,3203 & 0,0409 & 60,9961 & $0,000^{*}$ \\
\hline & Pendidikan suami & $-0,0652$ & 0,0420 & 2,4025 & 0,121 \\
\hline & Paritas & 0,2680 & 0,0366 & 53,7289 & 0,000 * \\
\hline & $\begin{array}{l}\text { Metode } \\
\text { persalinan }\end{array}$ & 0,9617 & 0,0525 & 335,6224 & $0,000^{*}$ \\
\hline
\end{tabular}

Pada model kedua, menunjukkan hasil yang sedikit berbeda dengan model pertama. Berdasarkan hasil pengolahan, terdapat lima variabel penjelas yang memiliki nilai $p$-value $<0,05$. Hal tersebut menunjukkan bahwa kelima variabel tersebut secara signifikan memengaruhi status pemberian ASI pertama dalam waktu satu jam setelah 
kelahiran. Kelima variabe penjelas tersebut adalah kunjungan antenatal, status bekerja ibu, tempat persalinan, paritas, dan metode persalinan. Berikut adalah persamaan yang diperoleh untuk model 2.

$$
\begin{aligned}
\operatorname{Logit}[\mathrm{P}(\mathrm{Y}>1 \mid \mathrm{x})]= & -1,0714-0,0572 \mathrm{umur}-0,0422 \text { pendidikan_ibu }+0,1802 \mathrm{anc}^{*}+ \\
& \text { 0,0896status_kerja* }+0,0188 \text { tempat_tinggal } \\
& \text { 0,3203tempat_persalinan* }+0,0652 \text { pendidikan_suami } \\
& \text { 0,2680paritas }{ }^{*}+0,9617 \text { metode_persalinan* }^{*}
\end{aligned}
$$

Keterangan $\left.\quad:{ }^{*}\right)$ Signifikan pada $\alpha=0,05$

Tabel 7 menunjukkan bahwa terdapat nilai odds ratio yang sama diantara dua model, yaitu status bekerja ibu, kunjungan antenatal care, dan metode persalinan. Dalam penginterpretasian ketiga variabel penjelas tersebut dapat dilakukan sama seperti menginterpretasi regresi logistik ordinal pada umumnya. Berdasarkan hasil tersebut, dapat diketahui bahwa ibu yang bekerja memiliki kecenderungan sebesar 1,0938 kali lebih besar untuk memberikan ASI pertama setelah kelahiran lebih awal, baik dalam waktu satu jam maupun satu hari setelah kelahiran, dibandingkan ibu yang tidak bekerja. Hasil tersebut sejalan dengan hasil penelitian yang diakukan oleh Nelvi (2004) dan Dewi (2013) yang mengungkapkan bahwa ibu yang bekerja cenderung untuk lebih mudah memperoleh informasi dari luar dibandingkan dengan ibu yang tidak bekerja. Salah satu jenis informasi yang diperoleh adalah tentang kesehatan anak, termasuk pemberian ASI dini atau IMD.

Tabel 7: Nilai odds ratio variabel penjelas yang secara signifikan memengaruhi status IMD untuk dua model persamaan

\begin{tabular}{clc}
\hline Model & \multicolumn{1}{c}{ Variabel } & Odds Ratio \\
\hline 1 & Status bekerja ibu & 1,0938 \\
& Tempat tinggal & 1,1185 \\
& Tempat persalinan & 1,6084 \\
& Antenatal care & 1,1974 \\
& Metode persalinan & 2,6162 \\
& Paritas & 1,4399 \\
& Status bekerja ibu & 1,0938 \\
& Tempat persalinan & 1,3775 \\
& Antenatal care & 1,1974 \\
& Metode persalinan & 2,6162 \\
& Paritas & 1,3074 \\
\hline
\end{tabular}

Di Indonesia, ibu yang melakukan kunjungan antenatal care sebanyak empat kali atau lebih memiliki kecenderungan sebesar 1,1974 untuk memberikan ASI pertama setelah kelahiran lebih awal dibandingkan ibu yang tidak melakukan 
kunjungan antenatal care atau yang melakukan kunjungan antenatal care kurang dari empat kali. Hasil tersebut disebabkan karena semakin banyak jumlah kunjungan yang dilakukan oleh ibu, maka pengetahuan ibu tentang proses dan tata cara menyusui lebih banyak dan mendalam. Pengetahuan tersebut juga termasuk kapan seorang ibu sebaiknya memberikan ASI pertama kepada bayinya setelah kelahiran. Ibu yang melahirkan dengan cara normal lebih cenderung memberikan ASI pertama lebih awal sebesar 2,6162 kali dibandingkan ibu yang melahirkan melalui operasi caesar. Hasil tersebut sejalan dengan hasil penelitian yang dilakukan oleh Acharya dan Khanal (2015).

Selanjutnya, terdapat pula variabel penjelas yang memiliki nilai odds ratio yang berbeda untuk setiap modelnya. Hal tersebut mengindikasikan bahwa pengaruh variabel penjelas tersebut berbeda untuk ibu yang memberikan ASI pertama dalam satu jam dan satu hari setelah melahirkan. Variabel penjelas tersebut adalah tempat persalinan dan paritas. Ibu yang melahirkan di tempat fasilitas kesehatan memiliki kecenderungan sebesar 1,6084 kali untuk memberikan ASI pertama dalam waktu satu hari setelah kelahiran, dan sebesar 1,3775 kali untuk memberikan ASI pertama dalam waktu satu jam setelah kelahiran. Hal tersebut dapat diartikan bahwa tempat persalinan di tempat fasilitas meningkatkan kecenderungan ibu untuk memberikan ASI pertama setelah kelahiran lebih awal dibandingkan ibu yang melahirkan di tempat nonfasilitas kesehatan.

Seorang ibu yang memiliki anak lebih dari satu (multipara) memiliki kecenderungan sebesar 1,4399 kali untuk memberikan ASI pertama dalam waktu satu hari setelah kelahiran, dan sebesar 1,3074 kali untuk memberikan ASI pertama dalam waktu satu jam setelah kelahiran dibandingkan ibu yang hanya memiliki satu anak. Hasil tersebut menunjukkan bahwa jumlah anak yang dimiliki oleh ibu berpengaruh signifikan terhadap pemberian ASI pertama setelah kelahiran, dimana ibu yang memiliki anak lebih dari satu cenderung untuk memberikan ASI pertama setelah kelahiran lebih awal, baik satu hari maupun satu jam, setelah kelahiran. Hal tersebut dikarenakan pengalaman yang dimiliki oleh ibu dalam menyusui anak sebelumnya menjadikan ibu lebih tau kapan harus memberikan ASI pertama kepada anaknya.

Terdapat satu variabel penjelas yang hanya berpengaruh pada salah satu model, yaitu tempat tinggal. Tempat tinggal hanya berpengaruh pada pemberian ASI pertama dalam waktu satu hari setelah kelahiran. Seorang ibu yang bertempat tinggal di wilayah perkotaan memiliki kecenderungan sebesar 1,1185 kali dibandingkan ibu yang tinggal di wilayah perkotaan. Dalam hal ini, ibu yang tinggal di wilayah perkotaan memiliki lebih banyak kemudahan dalam memperoleh pendidikan, informasi, sarana/prasarana kesehatan, dan akses menuju tempat fasilitas kesehatan. Hal inilah yang menyebabkan seorang ibu yang tinggal di wilayah perkotaan lebih cenderung untuk memberikan ASI pertama setelah kelahiran lebih awal. 


\section{Kesimpulan dan Saran}

\subsection{Kesimpulan}

Berdasarkan hasil dan pembahasan tersebut, kesimpulan yang dapat diambil adalah sebagai berikut:

1. Persentase wanita usia 15-49 tahun yang pernah melahirkan dalam waktu lima tahun sebelum pencacahan dalam melakukan Inisiasi Menyusu Dini satu jam setelah kelahiran di Indonesia pada tahun 2012 adalah sebesar 58,9 persen. Persentase wanita usia 15-49 tahun di Indonesia tahun 2012 yang melaksanakan Inisiasi Menyusu Dini satu jam setelah kelahiran tertinggi adalah pada ibu yang berpendidikan SMP ke bawah, melakukan kunjungan ANC minimal empat kali, tinggal di wilayah perkotaan, melahirkan di tempat fasilitas kesehatan, memiliki suami yang berpendidikan SMP ke bawah, memiliki jumlah anak lebih dari satu, dan melahirkan secara normal.

2. Berdasarkan hasil analisis regresi logistik ordinal, diperoleh sebanyak dua persamaan sebagai berikut:

- Pada persamaan pertama, determinan status IMD dalam waktu satu hari setelah kelahiran adalah kunjungan ANC, status bekerja ibu, tempat tinggal, tempat persalinan, metode persalinan, dan paritas.

- Pada persamaan kedua, determinan status IMD dalam waktu satu jam setelah kelahiran adalah kunjungan ANC, status bekerja ibu, tempat persalinan, metode persalinan, dan paritas.

3. Wanita usia 15-49 tahun yang pernah melakukan kunjungan antenatal care sebanyak empat kali atau lebih, bekerja, bertempat tinggal di wilayah perkotaan, melahirkan di tempat fasilitas kesehatan, melahirkan secara normal, dan memiliki anak lebih dari satu cenderung untuk lebih awal dalam melakukan IMD.

\subsection{Saran}

Berdasarkan kesimpulan yang diperoleh, saran yang diberikan adalah sebagai berikut:

1. Wanita usia 15-49 tahun diharapkan untuk melakukan kunjungan antenatal care minimal sebanyak empat kali secara lebih teratur dan serius agar mampu menerima informasi IMD lebih baik. Pemerintah, khususnya Kementerian Kesehatan juga diharapkan untuk melakukan sosialisasi terkait pentingnya kunjungan antenatal care kepada ibu hamil dengan cara melakukan kunjungan ke RT atau RW.

2. Wanita usia 15-49 tahun diharapkan untuk melakukan persalinan di tempattempat fasilitas kesehatan yang memiliki tenaga ahli kesehatan sehingga mampu membantu proses IMD dengan tahapan yang tepat. Pemerintah diharapkan untuk meningkatkan jumlah rumah sakit atau rumah bersalin, khususnya di wilayah 
perdesaan sehingga masyarakat semakin mudah untuk mengakses fasilitas kesehatan.

3. Wanita usia 15-49 tahun diharapkan untuk mengikuti saran-saran yang diberikan oleh tenaga ahli kesehatan untuk meningkatkan keberhasilan kemungkinan dalam melahirkan secara normal sehingga IMD dapat terlaksana tanpa terhambat adanya efek setelah operasi caesar.

4. Dengan adanya keterbatasan penelitian terkait dengan data, disarankan kepada penelitian selanjutnya untuk menggunakan data yang terbaru, yaitu SDKI 2017. Terkait dengan pemilihan variabel, disarankan untuk menambahkan variabel geografis atau spasial yang tidak tercakup di dalam penelitian ini sehingga dapat mengetahui faktor-faktor yang memengaruhi status IMD tidak hanya secara umum di Indonesia saja, namun juga dapat dilihat berdasarkan provinsi. Penelitian selanjutnya juga dapat lebih memfokuskan untuk melihat faktor-faktor yang memengaruhi IMD pada provinsi tertentu, misalnya Sumatera Utara yang memiliki persentase IMD paling rendah se-Indonesia.

\section{Daftar Pustaka}

Acharya, P., \& Khanal, V. (2015). The effect of mother's educational status on early initiation of breastfeeding: further analysis of three consecutive Nepal Demographic and Health Surveys. BMC Public Health, 15(1), 1069.

Agresti, A. (2010). Analysis of Ordinal Categorical Data (2 ${ }^{\text {nd }}$ ed). New Yok: John Wiley \& Sons.

Ari, E. \& Yildiz, Z. (2014). Parallel lines assumption in ordinal logistic regression and analysis approaches. International Interdisciplinary Journal of Scientific Research, 1(3), 8-23.

Dewi, R. (2013). Faktor-Faktor yang Mempengaruhi lbu Pasca Induksi Persalinan Melakukan Inisiasi Menyusu Dini. Fakultas IImu Keperawatan. Universitas Indonesia, Depok.

Edmond, K. M., Zandoh, C., Quigley, M. A., Amenga-Etego, S., Owusu-Agyei, S., \& Kirkwood, B. R. (2006). Delayed breastfeeding initiation increases risk of neonatal mortality. Pediatrics, 117(3), e380-e386.

Hosmer, D.W., Lemeshow, S., \& Sturdivant, R.X. (2013). Applied Logistic Regression: Third Edition. Canada: John Wiley \& Sons, Inc.

KEMENKES RI. (2013). Survei demografi dan kesehatan Indonesia 2012. Jakarta: Kementrian Kesehatan RI.

KEMENKES RI. (2014). Situasi dan Analisis ASI Eksklusif. Jakarta: Departemen Kesehatan Indonesia. 
Mullany, L. C., Katz, J., Li, Y. M., Khatry, S. K., LeClerq, S. C., Darmstadt, G. L., \& Tielsch, J. M. (2008). Breast-feeding patterns, time to initiation, and mortality risk among newborns in southern Nepal. The Journal of nutrition, 138(3), 599-603.

Nelvi. (2004). Faktor-Faktor yang Berhubungan dengan Inisiasi Pemberian ASI di RB Puskesmas Jakarta Pusat Tahun 2004. Fakultas Kesehatan Masyarakat. Universitas Indonesia, Depok.

Roesli, U. (2008). Inisiasi Menyusu Dini Plus ASI Eksklusif. Jakarta: Pustaka Bunda.

Suryani, D.N. \& Mularsih, S. (2011). Hubungan Dukungan Suami dengan Pelaksanaan Inisiasi Menyusu Dini pada lbu Post Partum di BPS Kota Semarang. Jurnal Dinamika Kebidanan, Vol. 1 No. 1.

Williams, R. (2006). Generalized ordered logit/partial proportional odds models for ordinal dependent variables. The Stata Journal, 6(1), 58-82. 